\title{
Application of material requirement planning method in raw materials planning on sardine product in PT. Blambangan Foodpackers Indonesia
}

\author{
*Susanti, H.D. \\ Department of Industrial Engineering, Faculty of Engineering, 17 Agustus 1945 Banyuwangi University, \\ Jalan Adi Sucipto, Banyuwangi, East Java, Indonesia
}

\author{
Article history: \\ Received: 13 May 2020 \\ Received in revised form: 2 \\ July 2020 \\ Accepted: 16 July 2020 \\ Available Online: 4 \\ September 2020
}

\section{Keywords:}

Inventory control

Material requirement

planning

Sardine product

DOI:

https://doi.org/10.26656/fr.2017.4(6).228

\begin{abstract}
PT. Blambangan Foodpackers Indonesia is one of the big companies in the Banyuwangi area and is a company engaged in the manufacturing industry that is a company processing canned fish. The number of constraints in planning raw material inventories that cause the occurrence of excess or accumulation of raw materials and shortages causes freezing of operational costs. The implementation of the material requirement planning (MRP) system is expected to be able to find out the optimal amount of raw material inventory and the right ordering time to meet production needs with optimal costs. This study was aimed to determine the exact lot size technique based on inventory costs and to compare the MRP method with inventory in the company based on total inventory costs. The research method used was the determination of the lot size and MRP system. The results showed that the lot for lot method for ASCK cans, ASCB cans, ASTB cans, and pasta, while EOQ for ASTK cans, ASEPK cans, sugar, salt and flour. The MRP system in each raw material can be used as an indicator to minimize total inventory costs when compared to the company's method during the previous period.
\end{abstract}

\section{Introduction}

Inventories are basic ingredients, goods in the process and actually finished goods that are considered as part of business assets that are ready or will be ready for sale (Ziukov, 2015). Inventory aims to obtain an optimal cost policy by minimizing the present net value of the total cost per unit time (Abdoli, 2016). Control of inventory in the supply chain is very important for companies to meet the demands of their customers as well as controlling costs. However, uncertainty can have an impact on supply and production processes (Koh and Saad, 2003). Inventory management is a key factor in the success of any organization and its function is to find sufficient quantities of stock that will meet demand without causing excess stock (Suryawanshi et al., 2018).

In fact, manufacturing companies use inventory management software by using MRP (Material Requirement Planning) to answer uncertainty. But more often, the effects of fluctuations greatly reduce the performance of the tool and cause high production costs, as well as uncertainty in demand (Wazed et al., 2009; Dolgui et al., 2013). safety time lead, and lot-sizing rules that can be used as supply variability controls in anticipation of uncertainty (Dolgui and Prodon, 2007).
The MRP system is a system that helps control demand-dependent inventories automatically (Hanson et al., 2015). The main goal is to get the right material to the right place, at the right time. This system uses information from the master production schedule, material bills, production cycle times and material requirements, the waiting time for suppliers in determining raw material orders and delivery times (Miclo et al., 2018). Availability planning in MRP is closely related to product returns, material restrictions, production scheduling, systems and material capacity planning, inventory control. and stochastic routes (Junior and Filho, 2012). Perspectives for control and planning have been developed from production operations on the internal to supply chain operations that connect suppliers, producers and customers using MRP (Olhager, 2013). The consideration of the MRP approach with the policy of POQ (Periodic Order Quantity) aims to find the optimal phase of MRP or respond to each period of POQ policy. The MRP approach using lead time will provide appropriate planning on inventory to meet customer needs (Louly and Dolgui, 2013).

The industrial sector is a sector that is quite reliable in the Indonesian economy, especially from the fisheries product processing industry sector. This makes the 
fishery products processing industry very influential in improving the economy because the fisheries sector is still the main producer of most Indonesian people as a maritime country. One of the fisheries product processing industries that use the commodity of sardines as the basic raw material in the production process is the fish canning industry.

The fishing industry can contribute to the national economy, innovation and employment. At present many companies in this industrial sector struggle to increase their capacity utilization, operational efficiency, and profitability (Bakhrankova et al., 2014). The fishing industry must also have the ability to integrate production scheduling and distribution planning because it will have an impact on efficiency and increase economic profits (Agustin et al., 2018).

Fish raw materials for the fishing industry are very difficult to predict, this is due to several factors such as traditional fishing boat infrastructure and bad weather. To anticipate these problems, companies need to have the right planning system starting from the system of ordering raw materials to reduce inventory costs. If the raw material ordered in small quantities will make the inventory empty in certain conditions so that the production process will run unstable. However, if the amount of ordering raw materials is very large, it will have an impact on the high cost of storage. Inventory is very influential on the carrying capacity of the company's operations. Without an inventory, the company cannot produce goods at any time and cannot meet customer demand (Sastri and Prasanti, 2018). For the long-term resilience of the food industry and as a holder of important information, producers must play an active role in reducing waste (Woolley et al., 2016).

PT. Blambangan Food Packers Indonesia (BFPI) located on port road no. 1 Muncar is a company focused on the sardines canning industry. PT. BFPI Muncar produces various types of sardines, one of which is sardine chili, tomato sardines, extra-spicy sardines and with two types of sardine sizes of 155 and $425 \mathrm{~g}$. Based on research and observations, it is known that in the operation of the production system at PT. BFPI has a problem regarding the supply of raw materials, where there is an error in the supply of raw materials with a production plan, a buildup of raw material inventories and frequent delays in the delivery for raw materials from the supplier. Therefore, it is expected that this research can provide suggestions or recommendations for improvements in the planning of raw materials for management to be able to operate more efficiently in the future.

To help solve the above problems, especially the issue of raw material planning, a MRP system has been developed. The use of the MRP method is expected to be able to meet the raw material needs appropriately and to determine the cost of its inventory more optimally so that later it will affect the smoothness of the production process and meet the target of consumer orders.

\section{Materials and methods}

This research was conducted at PT. BFPI in Banyuwangi Regency. Primary data is obtained from the production of $\mathrm{ABC}$ sardines, namely ASCK (ABC sardines, small chili), ASTK (ABC sardines, small tomatoes), ASEPK (ABC spicy small extra sardines), ASCB (ABC sardines, large chili), ASTB (ABC sardines, large tomatoes) and ASEPB (ABC sardine spicy extra). The raw materials to be studied are ASCK cans, ASCB cans, ASTK cans, ASTB cans, ASEPK cans, ASEPB cans, tomato paste, fine salt, granulated sugar, and Ctex flour obtained from the management of PT. BFPI. Data processing uses the MRP method of Economic Order Quantity (EOQ) and Lot For Lot (LFL) during April and May 2013.

EOQ is the determination of lot size with this technique which is very popular in traditional inventory systems. In this technique, the size of the lot is fixed. Determination of lots based on the cost of the message and the cost of storage, with the following formula.

$$
\mathrm{EOQ}=\sqrt{\frac{2 A D}{h}}
$$

Where A is booking fee per message, $\mathrm{D}$ is the average demand and $\mathrm{h}$ is the holding cost.

The advantage of using the EOQ technique is that orders are made greater than their net requirements so that if there is a change in production quality, the raw material inventory is available. The assumptions used in this study; 1) the demand for products is constant, uniform, and known 2) the price of per unit is constant, 3 ) the cost of storing per unit per year is constant, 4) the cost of ordering a message is constant, 4) the time between an order is made and the item received is constant, and 5) no there is a shortage of goods. The advantage of using the EOQ technique is that the ordering is greater than the net requirement so that if there is a change in the quality of the production, the raw material inventory is available.

LFL is a technique of determining the size carried out on the basis of discrete orders. The use of this technique aims to minimize the cost of saving, so with this technique, the cost of saving becomes zero. When viewed from the pattern of needs that have a discontinuous or irregular nature, then this LFL 
technique has good ability. This method contains a risk, that is if there is a delay in the delivery of goods. Besides this technique is often used in manufacturing production systems that have the nature of a permanent set-up in the production process. This technique seeks to eliminate the cost of storage of stored material inventory. But this technique cannot take economic advantage related to the exact order size, this technique also cannot be used if the raw materials used are few in the market so that the demand on time cannot be done.

\section{Results and discussion}

\subsection{The selection of the sizing lot method}

Once calculated using the three methods that are used as references, the next step is to compare the results of all three methods. The technique chosen for each raw material is not always the same, this is because the selection of the technique is based on which method produces the minimum cost of the three methods used. The table below will give a clear picture of the comparison of the three methods for each raw material.

From the data in Table 1, the most optimal type of method for each raw material can be determined. For example, for ASCK cans raw materials, from the two existing lot-sizing results, the LFL method (lot for lot) produces the least cost, which is IDR 4,020,000. Therefore, later in the preparation of the MRP table, the number of lots used for purchasing raw materials will be used as the calculation results from the LFL method. For more details, determining the lot sizing method to be used for each raw material can be shown in Table 2 .

Table 1. Comparison of results lot sizing

\begin{tabular}{lcc}
\hline \multicolumn{1}{c}{ Raw material } & $\begin{array}{c}\text { Lot For Lot } \\
\text { (IDR) }\end{array}$ & $\begin{array}{c}\text { EOQ } \\
\text { (IDR) }\end{array}$ \\
\hline ASCK cans & $4,020,000$ & $4,817,606$ \\
ASCB cans & $2,902,259$ & $3,557,221$ \\
ASTK cans & $3,451,184$ & $3,183,849$ \\
ASTB cans & $2,503,883$ & $2,837,866$ \\
ASEPK cans & $3,114,881$ & $2,612,848$ \\
ASEPB cans & $3,532,407$ & $3,691,704$ \\
Tomato Paste & $3,252,836$ & $3,818,370$ \\
Sugar & $3,116,684$ & $1,974,360$ \\
Salt & $2,137,585$ & 993,455 \\
Ctex Flour & $2,596,258$ & $1,024,132$ \\
\hline
\end{tabular}

Please note that the use of the lot sizing method as shown in the table above is not a standard rule, but the use of the lot sizing method depends on the amount of raw material requirements, also if there is a policy change regarding costs or changes in raw material prices. All of these affect the amount of lot-sizing calculation, therefore it is necessary to determine the period of planning for raw material requirements. Where after one period of the planning period is complete, it is necessary to recalculate the number of lots of raw material purchases. If changes occur in the planning period, the lot sizing also needs to be recalculated to maintain the accuracy of the results.

Table 2. Use of the lot sizing method for lot raw materials

\begin{tabular}{lcc}
\hline \multicolumn{2}{c}{ Raw Materials } & \multicolumn{2}{c}{ Methods Lot Sizing (IDR) } \\
\hline ASCK cans & LFL & $4,020,000$ \\
ASCB cans & LFL & $2,902,259$ \\
ASTK cans & EOQ & $3,183,849$ \\
ASTB cans & LFL & $2,503,883$ \\
ASEPK cans & EOQ & $2,612,848$ \\
ASEPB cans & LFL & $3,532,407$ \\
Tomato Paste & LFL & $3,252,836$ \\
Sugar & EOQ & $1,974,360$ \\
Salt & EOQ & 993,455 \\
Ctex Flour & EOQ & $1,024,132$ \\
\hline
\end{tabular}

\subsection{Raw material inventory analysis in the company}

The raw material inventory control system in the company starts with the production design from the marketing department and calculates the raw material requirements previously set by PPIC. Inventory control carried out by the company aims to expedite the production process and protect the company so as not to lack raw materials that can hinder the company's production activities.

Inventory control is also useful to anticipate excess raw materials which can increase excess storage costs. The cost of procuring raw materials includes the cost of ordering raw materials and the cost of storing raw materials per unit per week. The cost component is a component that becomes a reference in finding which technique is right to be used as a technique to control sardine raw material inventory. Data on raw material inventory control conducted by the company in April to May 2013 can be seen in the attachment of the company's actual raw material inventory.

Sardine raw material supplies during the period of April to May 2013, total inventory stored in warehouses for ASCK cans was 2,918,361 units, ASCB cans amounted to $1,157,167$ units, ASTK cans were 1,772,603 units, ASTB cans were 662,986 units, cans ASEPK is $1,657,495$ units, ASEPB cans are 1,333,669 units, tomato paste is $318,136.71 \mathrm{~kg}$, fine salt is $85,505.05 \mathrm{~kg}$, granulated sugar is $142,109.3 \mathrm{~kg}$ and for Ctex flour is $33,890.85 \mathrm{~kg}$.

\subsection{Calculation of raw material inventory costs in PT.Company}

BPI Indonesia issued a number of costs for the inventory of raw materials which can be divided into two types, namely ordering and storage costs. The cost of 
ordering raw materials is obtained from the result of ordering costs multiplied by the frequency of ordering raw materials for sardines. The greater the level of inventory of raw materials stored, the greater the cost of storage.

The total cost of raw material inventory during the April and May periods is the total cost between ordering raw materials and the cost of storing raw materials. Calculation of inventory costs in companies in the period April to May 2013 was IDR 6,277,972 for ASCK canned raw materials with an order frequency of 8 times, and the largest inventory cost that must be spent by the company is that ASCB cans are IDR 13,096,279. While the smallest inventory cost is for Ctex flour as much as IDR $2,006,061$ with order frequency of 3 orders. List of inventory costs of raw materials in the company can be shown in Table 3.

\subsection{Comparative analysis of inventory control methods the inventory}

The control of raw material for sardines is very important because it is the largest part of expenditure for controlling raw material inventory costs. If the expenditure for controlling sardine raw materials is minimal, the cost of controlling the overall raw material inventory can be reduced. Based on the calculation of the company's inventory control method with the MRP method during the April and May 2013 periods, a comparison can be made between the two based on the total inventory cost that must be done by the company.

The calculation results obtained that the MRP method produces inventory costs that are lower than the costs that must be incurred by the company, this is because the MRP method can reduce inventory levels, so the storage costs are low. In addition, the MRP method can also produce ordering frequencies that are lower than the order frequency made by the company. A comparison of the company's raw material inventory costs with the MRP method can be shown in Table 4.

The results of the comparison of total inventory costs between the methods carried out by the company and the MRP method, that the MRP method can minimize total inventory costs. In Table 4, it is known that the biggest savings are $75 \%$ of the company method with the ratio of the company's total inventory to ASCB cans of IDR 13,096,278.66 while with the MRP method the total inventory is IDR $3,258,974.25$.

Savings for ASTB cans are $24 \%$ with a ratio of inventory costs of IDR 3,722,505.96 for companies and

Table 3. List of raw material inventory costs in the company in April and May 2013

\begin{tabular}{lccccccc}
\hline \multirow{2}{*}{ Raw materials } & \multicolumn{3}{c}{ Cost order } & \multicolumn{4}{c}{ Storage } \\
\cline { 2 - 6 } & IDR/message & $\begin{array}{c}\text { Order } \\
\text { frequency }\end{array}$ & $\begin{array}{c}\text { Total message } \\
\text { costs (IDR) }\end{array}$ & $\begin{array}{c}\text { unit/Kg } \\
\text { (IDR) }\end{array}$ & $\begin{array}{c}\text { Amount of } \\
\text { inventory }\end{array}$ & $\begin{array}{c}\text { Total storage } \\
\text { costs (IDR) }\end{array}$ & $\begin{array}{c}\text { Total cost of } \\
\text { inventory (IDR) }\end{array}$ \\
\hline ASCK cans & 502,500 & 8 & $4,020,000$ & 0,98 & $2,304,053$ & $2,257,971,94$ & $6,277,972$ \\
ASCB cans & 502,500 & 7 & $3,517,500$ & 1,98 & $4,837,767$ & $9,578,778,66$ & $13,096,279$ \\
ASTK cans & 502,500 & 8 & $4,020,000$ & 0,98 & $3,161,244$ & $3,098,019,12$ & $7,118,019$ \\
ASTB cans & 502,500 & 4 & $2,010,000$ & 1,988 & 864,902 & $1,712,505,96$ & $3,722,506$ \\
ASEPK cans & 502,500 & 5 & $2,512,500$ & 1,19 & $2,889,671$ & $3,438,708,49$ & $5,951,208$ \\
ASEPB cans & 502,500 & 6 & $3,015,000$ & 2,19 & $1,053,949$ & $2,308,148,31$ & $5,323,148$ \\
Tomato Paste & 502,500 & 6 & $3,015,000$ & 10 & $492,206,71$ & $4,922,067,1$ & $7,937,067$ \\
Sugar & 502,500 & 4 & $2,010,000$ & 3,7 & $90,775,05$ & $335,867,685$ & $2,345,868$ \\
Salt & 502,500 & 6 & $3,015,000$ & 8,3 & $153,109,3$ & $1,270,809,19$ & $4,285,807$ \\
Ctex Flour & 502,500 & 3 & $1,507,500$ & 13 & 38350,85 & $498,561,05$ & $2,006,061$ \\
\hline
\end{tabular}

Table 4. Comparison of companies with MRP inventory cost

\begin{tabular}{|c|c|c|c|c|c|c|c|}
\hline \multirow[b]{2}{*}{ Raw Material } & \multicolumn{3}{|c|}{ Company methods } & \multicolumn{3}{|c|}{ MRP method } & \multirow[b]{2}{*}{$\begin{array}{l}\text { Savings } \\
(\%)\end{array}$} \\
\hline & $\begin{array}{c}\text { Cost Ordering } \\
\text { (IDR) }\end{array}$ & $\begin{array}{c}\text { Costs storage } \\
\text { (IDR) }\end{array}$ & $\begin{array}{l}\text { Total inventory } \\
\text { (IDR) }\end{array}$ & $\begin{array}{c}\text { Costs Ordering } \\
\text { (IDR) }\end{array}$ & $\begin{array}{c}\text { Costs storage } \\
\text { (IDR) }\end{array}$ & $\begin{array}{l}\text { Total inventory } \\
\text { (IDR) }\end{array}$ & \\
\hline ASCK cans & $4,020,000$ & $2,257,971,94$ & $6,277,971,94$ & $3,517,500$ & $19,296,20$ & $3,536,796,25$ & 44 \\
\hline ASCB cans & $3,517,500$ & $9,578,778,66$ & $13,096,278,66$ & $2,010,000$ & $1,248,974,25$ & $3,258,974,25$ & 75 \\
\hline ASTK cans & $4,020,000$ & $3,098,019,12$ & $7,118,019,12$ & $1,005,000$ & $3,067,110,75$ & $4,072,110,75$ & 43 \\
\hline ASTB cans & $2,010,000$ & $1,712,505,96$ & $3,722,505,96$ & $2,010,000$ & $801,494,06$ & $2,811,494$ & 24 \\
\hline ASEPK cans & $2,512,500$ & $3,438,708,49$ & $5,951,208,49$ & $1,005,000$ & $1,607,925,63$ & $2,612,925,50$ & 56 \\
\hline ASEPB cans & $3,015,000$ & $2,308,148,31$ & $5,323,148,31$ & $3,517,500$ & $15,010,26$ & $3,532,510,25$ & 34 \\
\hline Tomato Paste & $3,015,000$ & $4,922,067,10$ & $7,937,067,10$ & $2,512,500$ & $1,245,377,88$ & $3,757,878$ & 53 \\
\hline Sugar & $2,010,000$ & $335,867,69$ & $2,345,867,69$ & 502,500 & $529,740,75$ & $1,032,240,75$ & 56 \\
\hline Salt & $3,015,000$ & $1,270,807,19$ & $4,285,807,19$ & $1,005,000$ & $1,006,781,50$ & $2,011,781,50$ & 53 \\
\hline Ctex Flour & $1,507,500$ & $498,561,05$ & $2,006,061,05$ & 502,500 & $584,951,88$ & $1,087,451,88$ & 46 \\
\hline Total & & & $58,063,935,51$ & & & $27,714,163,13$ & \\
\hline
\end{tabular}


IDR 2,811,494 for the MRP method. The raw material for tomato paste is a saving of 53\% with a total cost of IDR 7,937,067.10. For the company method and the MRP method IDR 3,757,878. From the results of these comparisons that with the MRP method, the company will minimize the cost of inventory which can later reduce the company's operating costs.

Production planning is usually done in stages for products and resources. Production resources are combined into aggregates of machines or labor resources. When planning production planning, the availability of raw materials and components must also be considered. The final item usually consists of many fabricated components and sub-assemblies, which must be available in the production system to ensure the execution of the production plan. MRP works on shorter time horizons and provides supply plans for these demand-dependent items in a coordinated and systematic manner (Vollman et al., 1992). Aggregate production planning and material requirements planning are activities that are highly dependent and have a strong impact on production performance (Harris et al., 2002).

Traditional MRP systems have weaknesses, one of which is the neglect of uncertainty as it refers to the demand and supply quantities. Whereas the modern MRP concept deals with the uncertainty by incorporating safety stock and scrap benefits into the calculation of order releases. However, this concept failed to find a solution in addressing risk protection measures. The application of analysis of stochastic controls and the performance of the control rules generated by the MRP can be assessed and how the appropriate control parameters for the MRP can be determined (Inderfurth, 2009). The MRP technique can be used to conduct supply requests, calculate initial raw material requirements and production planning. The master production schedule and the bill of materials show the material to be requested, the order scheduling, the time of the production cycle and the supplier carries out activities on all factors together in determining when the order should be made. This MRP technique begins with phased planning by calculating material requirements and scheduling requests and optimizing inventory. This MRP system will control adequate inventory and ensure that the needed materials are available when needed (Dinesh et al., 2014). Propose that if the MRP grid can be activated through the process of data distribution, it will have an impact on the work improvement process (Lee et al., 2007).

\section{Conclusion}

The right lot size is lot for lot with a total inventory of 4,020,000. The inventory costs for two months reached IDR 58,063,935.51 while the MRP method totaled inventory costs for all raw materials IDR $27,714,163.13$. While for the average savings of all raw materials around $48.4 \%$. Suggestions from this study are; 1) companies need to pay attention to the accuracy of raw material requirements in accordance with specified specifications, 2) companies need to pay attention to the time needed starting from ordering materials to arriving at the company (lead time). With the accuracy of the lead time can determine when to start ordering raw materials in accordance with the requirements so that there is no delay or accumulation of raw materials, and 3) the lot sizing method can be used as an initial calculation in ordering each period so that the optimal order amount can be known to reduce ordering costs storage costs.

\section{Conflict of interest}

Authors declare no conflict of interest.

\section{References}

Abdoli, M. (2016). Inventory model with variable demand rate under stochastic inflation for deteriorating and ameliorating items with permissible delay in payment. International Journal of Operational Research, 27(3), 375-388. https:// doi.org/10.1504/IJOR.2016.078935

Agustin, Mawengkang, H. and Mathelinea, D. (2018). Decision model for planning and scheduling of seafood products considering traceability. In IOP Conference Series: Materials Science and Engineering, 300, $012018 . \quad \mathrm{https} / / /$ doi.org/10.1088/1757-899X/300/1/012018

Bakhrankova, K., Midthun, K.T. and Uggen, K.T. (2014). Stochastic optimization of operational production planning for fisheries. Fisheries Research, 157, 147-153. https://doi.org/10.1016/ j.fishres.2014.03.018

Dinesh, E.D., Arun, A.P. and Pranav, R. (2014). Material requirements planning for automobile service plant. International Journal of Innovative Research in Science, Engineering and Technology, 3(3), 11711175.

Dolgui, A. and Prodhon, C. (2007). Supply planning under uncertainties in MRP environments: A state of the art. Annual Reviews in Control, 31(2), 269-279. https://doi.org/10.1016/j.arcontrol.2007.02.007

Dolgui, A., Ammar, O.B., Hnaien, F. and Louly, M.A. (2013). A state of the art on supply planning and inventory control under lead time uncertainty. 
Studies in Informatics and Control, 22(3), 255-268. https://doi.org/10.24846/v22i3y201302

Hanson, O., Ackah, D. and Agboyi, M. (2015). Assessing the Impact of Efficient Inventory Management in Organization. International Journal of Advanced Research in Computer Science and Software Engineering, 5(8), 86-103.

Harris, B., Lewis, F. and Cook, D.J. (2002). A matrix formulation for integrating assembly trees and manufacturing resource planning with capacity constraints. Journal of Intelligent Manufacturing, 13 (4), 239-252. https://doi.org/10.1023/ A:1016060009229

Inderfurth, K. (2009). How to protect against demand and yield risks in MRP systems. International Journal of Production Economics, 121(2), 474-481. https://doi.org/10.1016/j.ijpe.2007.02.005

Junior, M.L. and Filho, M.G. (2012). Production planning and control for remanufacturing: literature review and analysis. Production Planning and Control, 23(6), 419-435. https:// doi.org/10.1080/09537287.2011.561815

Koh, S.C.L. and Saad, S.M. (2003). MRP-controlled manufacturing environment is disturbed by uncertainty. Robotics and Computer-Integrated Manufacturing, 19(1-2), 157-171. https:// doi.org/10.1016/S0736-5845(02)00073-X

Lee, H.G., Na, H.B., Shin, K., Jeong, H.I. and Park, J. (2007). Performance improvement study for MRP part explosion in ERP environment. The International Journal of Advanced Manufacturing Technology, 35(3-4), 309-324. https:// doi.org/10.1007/s00170-006-0718-9

Louly, M.A. and Dolgui, A. (2013). Optimal MRP parameters for a single item inventory with random replenishment lead times, POQ policy and service level constraints. International Journal of Production Economics, 143(1), 35-40. https:// doi.org/10.1016/j.ijpe.2011.02.009

Miclo, R., Lauras, M., Fontanili, F., Lamothe, J. and Melnyk, S.A. (2018). MRP Demand Driven: assessment of a new approach to materials management. International Journal of Production Research, 57(1), 166-181.. https:// doi.org/10.1080/00207543.2018.1464230

Olhager, J. (2013). Evolution of operations planning and control: from production to supply chains. International Journal of Production Research, 51(23 -24), 6836-6843. https:// doi.org/10.1080/00207543.2012.761363
Sastri, S.E. and Prasanti, N. (2018). The decision making of inventory system using Monte Carlo Simulation: a case study. Decision Making, 6(1), 5-7.

Suryawanshi, N., Gore, S., Prasad Lawand, P. and Patel, S. (2018). Inventory management system. International Research Journal of Engineering and Technology, 5(10), 1159-1162.

Vollman, T.E., Berry, W.L. and Whybark, D.C. (1992). Manufacturing planning and control systems. Burr Ridge Ill: Richard D. Irwin

Wazed, M., Shamsuddin, A. and Yusoff, N. (2009). Uncertainty Factors in Real Manufacturing Environment. Australian Journal of Basic and Applied Sciences, 3(2), 342-351.

Woolley, E., Garcia-Garcia, G., Tseng, R. and Rahimifard, S. (2016). Manufacturing resilience via inventory management for domestic food waste. Procedia CIRP, 40, 372-377. https:// doi.org/10.1016/j.procir.2016.01.070

Ziukov, S. (2015). A literature review on models of inventory management under uncertainty. Business Systems and Economics, 5(1), 26-35. https:// doi.org/10.13165/VSE-15-5-1-03 